\title{
Translocation of BCR to Chromosome 9: A New Cytogenetic Variant Detected by FISH in Two Ph-Negative, BCR-Positive Patients With Chronic Myeloid Leukemia
}

\author{
Anne Hagemeijer, Arjan Buijs, Elizabeth Smit, Bart Janssen, Geert-jan Creemers, Dorien Van der Plas, and \\ Gerard Grosveld \\ Department of Cell Biology and Genetics, Erasmus University (A.H., A.B., E.S., D.V.d.P., G.G.), Department of Clinical Genetics, \\ Academic Hospital Dijkzigt (B.J.), and Dr. Daniel den Hoed Cancer Centre (G.-J.C.), Rotterdam, The Netherlands
}

Leukemic cells from two patients with Philadelphia-negative chronic myeloid leukemia (CML) were investigated: 1) Cytogenetics showed a normal 46,XY karyotype in both cases, 2) molecular studies revealed rearrangement of the $M-B C R$ region and formation of $B C R-A B L$ fusion mRNA with b2a2 (patient I) or b3a2 (patient 2) configuration, and 3) fluorescence in situ hybridization (FISH) demonstrated relocation of the $5^{\prime} B C R$ sequences from one chromosome 22 to one chromosome 9. The $A B L$ probe hybridized to both chromosomes 9 at band $q 34$, while two other probes which map centromeric and telomeric of $B C R$ on 22.q I l hybridized solely with chromosome 22. For the first time, a $B C R-A B L$ rearrangement is shown to take place on $9 q 34$ instead of in the usual location on $22 q \mathrm{ll}$. A rearrangement in the latter site is found in all Ph-positive CML and in almost all investigated CML with variant $\mathrm{Ph}$ or Ph-negative, BCR-positive cases. The few aberrant chromosomal localizations of $B C R-A B L$ recombinant genes found previously were apparently the result of complex and successive changes. Furthermore in patient 2, both chromosomes 9 showed positive FISH signals with both $A B L$ and $B C R$ probes. Restriction fragment length polymorphism (RFLP) analysis indicated that mitotic recombination had occurred on the long arm of chromosome 9 and that the rearranged chromosome 9 was of paternal origin. The leukemic cells of this patient showed a duplication of the $B C R-A B L$ gene, analogous to duplication of the Ph chromosome in classic CML. In addition they had lost the maternal alleles of the $9 q 34$ chromosomal region. The lymphocytes of patient 2 carried the maternal chromosome 9 alleles and were Ph-negative as evidenced by RFLP and FISH analyses, respectively. Genes Chrom Cancer 8:237-245 (1993). (c) 1993 Wiley-Liss, Inc.

\section{INTRODUCTION}

The $\mathrm{t}(9 ; 22)(\mathrm{q} 34 ; \mathrm{q} 11)$, i.e., the Philadelphia (Ph) translocation, is the cytogenetic hallmark of chronic myeloid leukemia (CML) in which it is observed in more than $90 \%$ of the cases. Molecularly, the translocation results in the formation of a chimeric $B C R-A B L$ gene that encodes a chimeric BCR-ABL protein. The chromosome 22 breakpoint is generally, but not exclusively, located in a $5 \mathrm{~kb} B g / \mathrm{II}$ fragment of the $B C R$ gene, the so-called major breakpoint cluster region (M-BCR). Depending upon the position of the breakpoint within $\mathrm{M}-\mathrm{BCR}$, two exons (b2 and b3) can be spliced to exon a2 of the $A B L$ gene to form the chimeric $B C R$ $A B L$ mRNA (Heisterkamp et al., 1985).

Cytogenetic variants of the $\mathrm{Ph}$ translocation can be studied by Southern blotting to demonstrate a rearrangement in the M-BCR or by RNA-PCR to show the specific junction type, b2a2 or $\mathrm{b} 3 \mathrm{a} 2$, in the mRNA of the recombinant gene. We and others have demonstrated that the cytogenetic variants of the $\mathrm{Ph}$ (simple, complex, masked $\mathrm{Ph}$ ) resulted in the same molecular $B C R-A B L$ recombination as in the standard $\mathrm{Ph}$ (Hagemeijer et al., 1984, 1985; Bartram et al., 1985; Morris et al., 1988; Dubé et al., 1989).
A small number of patients with CML do not show any evidence of a $\mathrm{Ph}$ chromosome. The majority of these have a normal karyotype, some have abnormalities involving chromosome 9 at band q34 or other changes, but invariably the chromosome 22 appears normal. When investigated by molecular means, some cases show evidence of an M-BCR rearrangement or a $B C R-A B L$ mRNA. The remaining cases are Ph-negative cytogenetically and molecularly and show slightly different pathological features and shorter survival (Martiat et al., 1991; Van der Plas et al., 1991).

Metaphase cells from $\mathrm{Ph}$-negative but molecularly M-BCR-positive CML patients have been studied using in situ hybridization (ISH) with probes specific for the $A B L$ and $B C R$ genes. This technique has demonstrated co-localization of the probes and by inference the genes map to the same chromosomal band. In at least six cases, translocation of $A B L$ to chromosome 22 was demonstrated (Ganesan et al., 1986; Morris et al., 1986; Dreazen

Received February 9, 1993; accepted May 25, 1993

Address reprint requests to Dr. Anne Hageneijer, Department of Cell Biology and Genetics, Erasmus University, P.O. Box 1738, 3000 DR Rotterdam, The Netherlands. 
et al., 1987; Inazawa et al., 1989). We report 2 CML patients with a normal leukemic karyotype who showed the recombined $B C R-A B L$ gene located in chromosome 9 at band q34. In one of the cases, there was evidence for somatic recombination giving rise to a population with two chromosomes 9 carrying the $B C R-A B L$ gene.

\section{CASE REPORTS}

\section{Patient I}

J.W. was admitted with a recent history of weight loss $(5 \mathrm{~kg})$ and appearance of tumors on the head. There were no complaints of dyspnoea, dizziness, or headache. Physical examination showed a pale 22-year-old male with a congenital malformation of the thorax and right hand, with three tumors on his head with a size of $2 \times 3 \mathrm{~cm}$ each, and enlarged lymph nodes in the submandibular and axillar region $(3 \times 3 \mathrm{~cm})$. There was splenomegaly $8 \mathrm{~cm}$ below the left costal margin but no hepatomegaly. Fundoscopy showed dilated tortuous blood vessels and numerous hemorrhages in the retina. Laboratory investigations revealed a hemoglobin of $4.9 \mathrm{mmol} / \mathrm{l}$, platelets $263 \times 10^{9} / \mathrm{l}$, and leucocytes of $405 \times 10^{9} / 1$ with $13 \%$ basophils, $3 \%$ eosinophils, $7 \%$ band forms, $32 \%$ neutrophils, $12 \%$ promyelocytes, $19 \%$ myelocytes, and $14 \%$ metamyelocytes. Serum LDH was 900 U/1. Leucocyte alkaline phosphatase was absent. The bone marrow was hypercellular with a myeloid/erythroid ratio of $8: 1$, a prominent increase in basophils, and a normal karyotype. Treatment with leukapheresis and hydroxyurea produced a good response initially. Two months later the patient developed thrombocytosis and became unresponsive to hydroxyurea. Bone marrow examination showed a lymphoblastic crisis and an abnormal karyotype, 47,XY, + mar (JSCN 1991). The patient was treated with multiple combination chemotherapy regimens without success. He died 10 months after diagnosis.

\section{Patient 2}

W.K. was referred to the hospital because of hyperleucocytosis found at a routine laboratory analysis. He had a slight prostatism and a recent loss of weight $(5 \mathrm{~kg})$. Physical examination showed a healthy, 49-year-old male with splenomegaly $6 \mathrm{~cm}$ below the left costal margin. Laboratory investigations revealed a hemoglobin of $6.8 \mathrm{mmol} / \mathrm{l}$, platelets $156 \times 10^{9} / 1$, and leucocytes $322 \times 10^{9} / \mathrm{l}$.

Microscopic examination of a peripheral blood smear showed myeloid cells at all stages of devel- opment with some hypersegmented forms. There were $2 \%$ basophils, $3 \%$ eosinophils, $15 \%$ bands, $48 \%$ neutrophils, $2 \%$ blasts, $7 \%$ promyelocytes, $17 \%$ myelocytes, and $6 \%$ metamyelocytes. Serum LDH was $1,017 \mathrm{U} / \mathrm{l}$. Leucocyte alkaline phosphatase activity was absent. The bone marrow was hypercellular with a myeloid/erythroid ratio of 40:1, no increase in bone marrow blasts, and a normal karyotype.

Treatment with hydroxyurea resulted in a reduction in spleen size and peripheral leucocyte counts. The patient has been followed for about 9 months. His disease is still in chronic phase but is very difficult to stabilize with highly variable WBC. He has an HLA-identical MLC-negative brother, and an allogeneic bone marrow transplantation is planned.

\section{MATERIALS AND METHODS}

\section{Patient Material and Cytogenetics}

Bone marrow and blood cells from both patients were obtained at diagnosis and at various times during the course of the disease. Cytogenetic analysis was carried out according to our standard procedure (Hagemeijer et al., 1979). Diagnostic material of both cases was kept frozen in 10\% DMSO in liquid $\mathrm{N}_{2}$ and thawed for molecular studies. New cultures of thawed diagnostic bone marrow from patient 1 were used for FISH analyses. The same cultures were used for cytogenetic and in situ hybridization studies of patient 2 .

\section{Southern Blotting}

DNA was extracted from bone marrow cells of both patients and from a normal thymus. To detect a rearrangement of the M-BCR, Southern blots containing DNA, digested with EcoRI, BamHI, $H i n d I I I$, and $B g A I$ were hybridized to three probes: 1) 5' BCR: a $2 \mathrm{~kb}$ BglI-HindIII fragment, 2) 3' BCR, a $1.2 \mathrm{~kb}$ HindIII-Bg/II fragment, and 3) the universal BCR probe (Oncogene Sciences, Mineola, NY).

To perform RFLP analysis of chromosome 9, DNA from bone marrow and peripheral blood from patient 2 was digested with BstXI, TaqI, and HindIII, blotted and hybridized with probes 26p (locus D9S5, obtained from ATCG, Rockville, MD), hAK1B3.25 (AK1, N.T. Bech-Hansen), ASSg1 (ASS, ATCC), MCT136 (D9S10, Y. Nakamura), and EFD126.3 (D9S7, Y. Nakamura). DNA of the patient's mother, obtained from peripheral blood, was similarly digested with TaqI and HindIII, blotted, and hybridized with 
EFD126.3, hAK1B3.25, and ASSG1, sequentially. The parental origin of each allele was deduced from the haplotypes.

\section{RNA-PCR Analysis}

Total RNA was extracted by the guanidine-thiocyanate method (Chomczynski and Sacchi, 1987). Using antisense $A B L$ primer a 3 and reverse transcriptase (Superscript, Gibco BRL, Grand Island, NY), cDNA was obtained and subsequently amplified using 2.5 units Taq polymerase (Boehringer Mannheim, Indianapolis, IN) in the presence of sense primers of $B C R$ gene $\mathrm{b} 2$ and 1 st exon e1. The technique, primers, and detection oligonucleotides were as described by Hermans et al. (1988). As internal positive control in the PCR, an $A B L$ fragment was amplified (Van der Plas et al., 1989). Twenty-four cycles of amplification were performed. The samples were electrophoresed and transferred to nylon filters (Zetaprobe), which were hybridized to ${ }^{32} \mathrm{P}$ end-labeled oligonucleotides, spanning the $\mathrm{e} 1-\mathrm{a} 2$ and $\mathrm{b} 2-\mathrm{a} 2$ and $\mathrm{b} 3-\mathrm{a} 2$ junctions. After hybridization the blots were washed and exposed to Fuji XR films (Tokyo, Japan).

\section{Fluorescence In Situ Hybridization (FISH)}

The probes were labeled by standard nick translation using either biotin-16-dUTP or digoxigenin11-dUTP (both from Boehringer-Mannheim). In double color FISH a mixture of two differently labeled probes was used. After heat denaturation, 25 to $50 \mathrm{ng}$ of probe was preannealed with $10 \mu \mathrm{g}$ of Cot-1 DNA for $1-3 \mathrm{hr}$ at $37^{\circ} \mathrm{C}$. The hybridization mixture contained the probes and Cot-1 DNA in $50 \%$ formamide, $10 \%$ dextran-sulphate in $2 \times$ SSCP. All details concerning pretreatment of slides, hybridization, washing, and immunochemical detection were as reported (Arnoldus et al., 1990). The probes used were 1) Cos-ABL-18, a 40 $\mathrm{kb}$ fragment containing the 3 ' coding region of the human $A B L$ gene, 2) Cos-BCR-16 containing a 32 $\mathrm{kb}$ fragment representing most of the first exon and part of the first intron of $B C R, 3) \operatorname{Cos} \lambda 3.1$, a cosmid containing sequences of the constant part of the $I G L$ gene that maps on chromosome 22 centromeric of $B C R, 4) 40 \mathrm{D} 2$, a cosmid containing sequences that map on $22 \mathrm{q} 11$ a few megabases telomeric of the $B C R$ gene, and 5) pHUR98, a satellite III DNA probe, was used at low concentration (5 $\mathrm{ng} / 10 \mu \mathrm{l})$. This probe recognizes specifically the polymorphic paracentromeric region of chromosome 9. It was used to facilitate the identification of chromosomes 9 in the metaphase cells. Whenever possible, 20 to 35 metaphases were scored

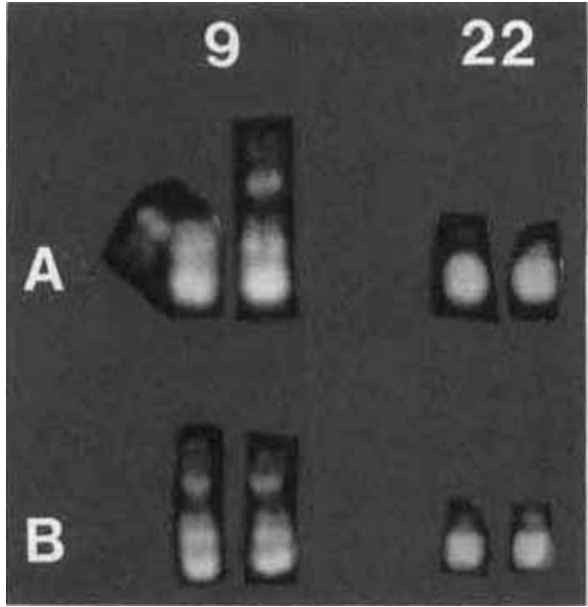

Figure I. Partial karyotype showing apparently normal pairs of chromosomes 9 and 22 of patient $I(\mathbf{A})$ and patient 2 (B). R-bands with acridine orange.

with each probe. Chromosomes were identified by DAPI banding or by combined hybridization with centromere specific probes.

\section{RESULTS}

\section{Cytogenetics}

Patient 1 showed, at diagnosis, a normal karyotype $(46, X Y)$ in 44 bone marrow metaphase cells. In particular, using various banding techniques, no structural aberrations were seen on chromosomes 9 and 22 (Fig. 1A). Three months later, during blast crisis, the 32 karyotyped metaphases showed 47 chromosomes, with an extra marker that looked like a slightly elongated chromosome 21 . The remaining 46 chromosomes appeared structurally normal. After blast crisis therapy, the percentage of cells with 47 chromosomes regressed but never disappeared. Patient 2 bone marrow cells showed a normal 46, XY karyotype in all 32 metaphase cells analyzed at diagnosis (Fig. 1B).

\section{Molecular Investigations of $B C R$ and $A B L$}

The results of Southern blotting analysis are given in Table 1. The presence of aberrant restriction fragments in the various digests indicated rearrangement of the M-BCR in both patients.

The results of PCR amplification of cDNA followed by hybridization to breakpoint specific oligonucleotides are shown in Figure 2. A 319 base pair (bp) fragment corresponding to $\mathrm{b} 2-\mathrm{a} 2$ joining in the $B C R-A B L$ mRNA was found in patient 1. A $394 \mathrm{bp}$ fragment corresponding to b3-a2 joining was found in patient 2 . As expected, neither $\mathrm{b} 2-\mathrm{a} 2$ 
TABLE I. Approximate Size in of Restriction Fragments Observed in DNA of Patients I and 2 After Southern Hybridization With M-BCR Probes ${ }^{\mathrm{a}}$

\begin{tabular}{|c|c|c|c|c|}
\hline \multirow[b]{2}{*}{ Restriction Fragment } & \multicolumn{3}{|c|}{ Patient I } & \multirow{2}{*}{$\frac{\text { Patient } 2}{\text { Universal BCR }}$} \\
\hline & Probes 5' BCR & $3^{\prime} \mathrm{BCR}$ & Universal BCR & \\
\hline $\begin{array}{l}\text { BgllI } \\
\text { BamHI } \\
\text { HindIII } \\
\text { EcoRI }\end{array}$ & $\begin{array}{l}6,4.8^{\mathrm{b}} \\
14,12^{\mathrm{b}} \\
\text { N.D. } \\
\text { N.D. }\end{array}$ & $\begin{array}{l}4.8^{b}, 3.5 \\
6,3.2^{b} \\
\text { N.D. } \\
\text { N.D. }\end{array}$ & $\begin{array}{l}6,4.8^{b}, 3.5,2.3^{b}, 1.1^{b} \\
\text { N.D. } \\
\text { N.D. } \\
\text { N.D. }\end{array}$ & $\begin{array}{l}8^{\mathrm{c}}, 4.8^{+}, 2.3^{\mathrm{b}}, 1.1^{\mathrm{b}} \\
12^{\mathrm{b}}, 10^{\mathrm{d}}, 3.2^{\mathrm{b}} \\
15,9.5^{\mathrm{b}}, 4.6^{\mathrm{b}} \\
18 \mathrm{~kb}^{\mathrm{b}}\end{array}$ \\
\hline
\end{tabular}

${ }^{\mathrm{a} N . D .}=$ no data due to incomplete digestion of DNA.

bGermline fragment also present in control DNA, aberrant fragments in bold.

'Aberrant fragment strongly expressed.

'Very weakly expressed aberrant fragment.
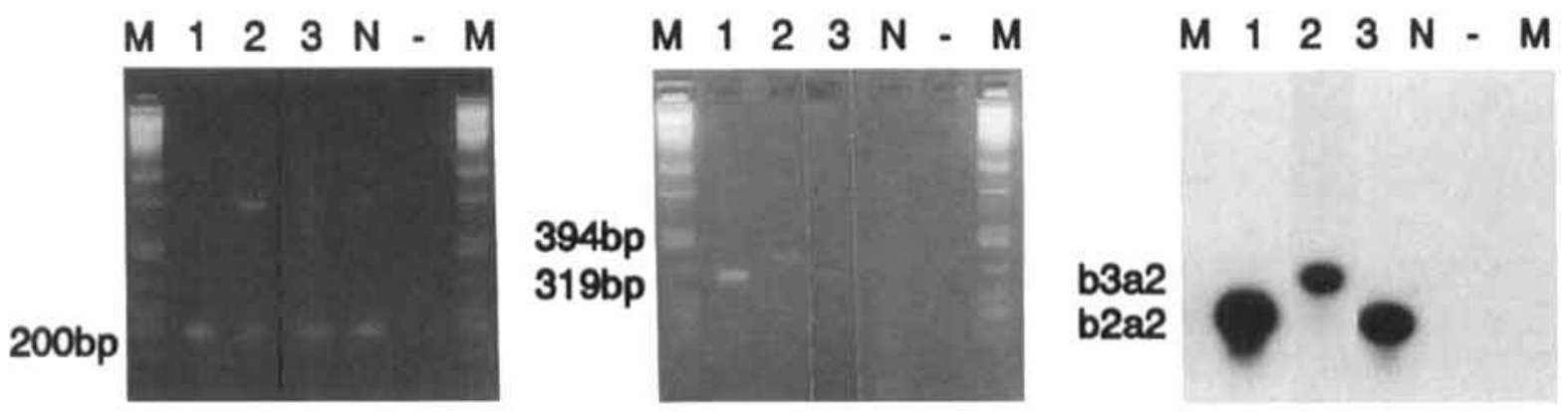

Figure 2. RNA-PCR analysis of patient I (lane I), patient 2 (lane 2), a Ph-positive CML positive control (lane 3), and a normal healthy control (lane $\mathbf{N}$ ). The empty lane is a negative control using distilled

nor b3-a2 joining was detected in the leucocytes of a healthy control.

\section{Fluorescence In Situ Hybridization (FISH)}

Most of the FISH analyses were performed with probes labeled with biotin and detected with avidin FITC. Using fluorescene microscopy, the yellow-green hybridization signal was easily detected on the red background of propidium iodide stained chromosomal DNA.

The results are illustrated in Figures 3 and 4 and summarized in 'Table 2. In a normal control, the $A B L$ probe hybridized to both chromosomes 9 at band $\mathrm{q} 34$ and the BCR probes to both chromosomes 22. In CML controls with a standard $t(9 ; 22)$, Cos-ABL-18 hybridized to the normal 9 at band $\mathrm{q} 34$, and the 22q- and Cos-BCR-16 hybridized to 22 and 22q- (data not shown). In both patients the $A B L$ probe hybridized to both chromosomes 9 at band $\mathrm{q} 34$, as it did in normal individuals. The $B C R$ water instead of RNA. A: amplification of $A B L$ internal fragment; B: amplification of $B C R-A B L$ junction fragment; $C$ : hybridization with junction specific oligonucleotides. $M=$ DNA size markers.

probe in patient 1 showed two signals, one on chromosome 9 and one on chromosome 22. In patient 2, three $B C R$ signals were seen in most metaphases, on one chromosome 22 and on both chromosome bands 9q34 (Fig. 4). The aberrant localization of $B C R$ on chromosome 9 was confirmed independently in both patients using cohybridization of the $B C R$ probe and pHUR98, a probe specific for the paracentromeric region of chromosome 9.

In both patients, the two remaining probes that map centromeric and telomeric of $B C R$ on chromosome 22 hybridized exclusively to both chromosomes 22. These results are best interpreted by suggesting an insertion of the $5^{\prime}$ part of the $B C R$ gene within or at the $5^{\prime}$ side of the $A B L$ gene on one chromosome 9. In patient 2 , both chromosomes 9 showed $B C R$ as well as $A B L$ signals in 17 of the 20 metaphases analyzed. This could be due to duplication of the rearranged chromosome 9 

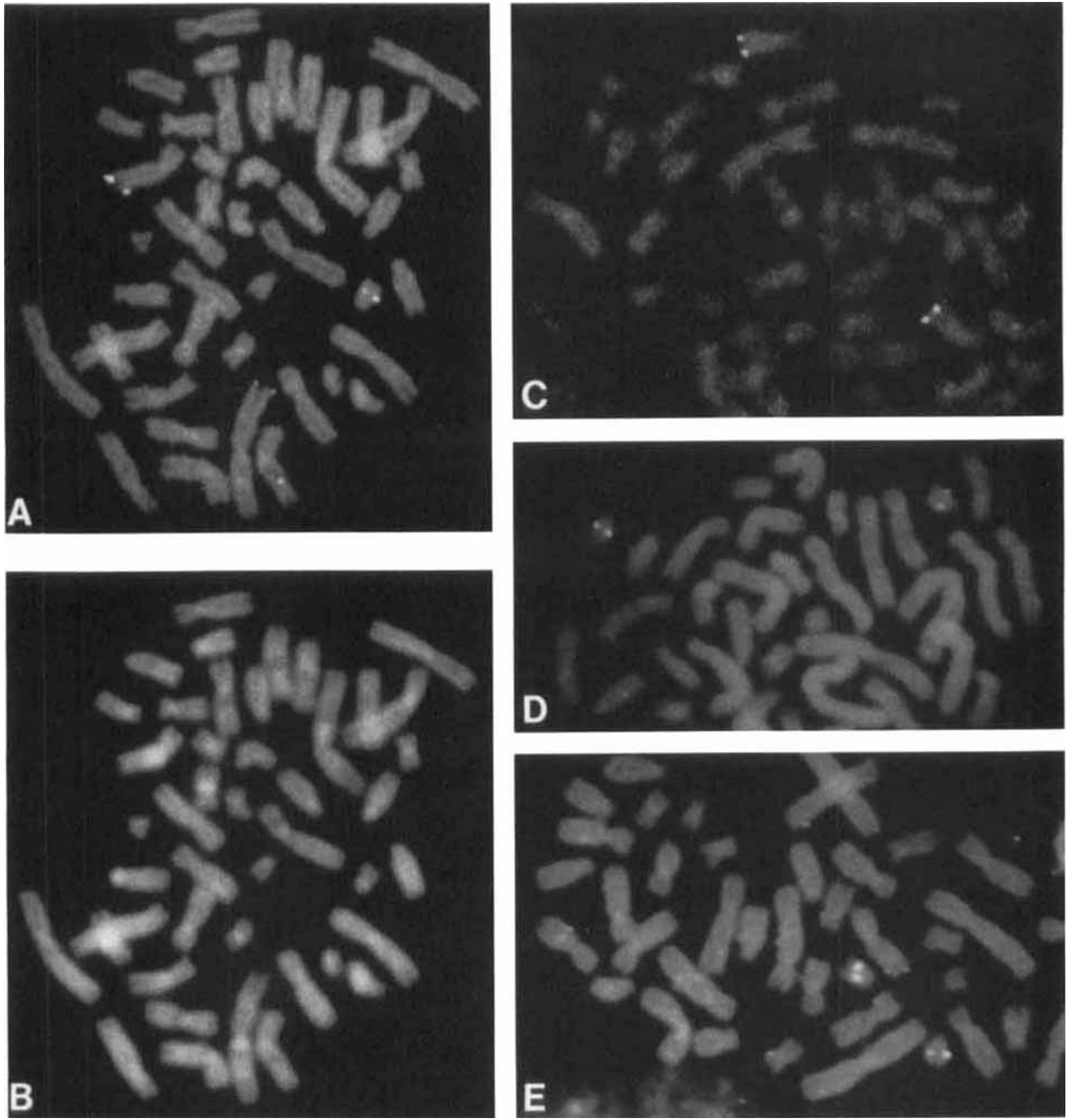

Figure 3. Partial metaphases from patient I showing the results of FISH. A: Cos-BCR-16 probe shows clear hybridization signal on one chromosome 22 and one chromosome 9. B: DAPI staining of the same metaphase cell. C: Cos-ABL-18 probe on two chromosomes 9. D: $\operatorname{Cos} \lambda 3.1$ on both chromosomes 22 and E: Cos-40D2 also on both chromosomes 22.

with loss of the normal 9 or mitotic recombination of part of chromosome 9. Whatever the mechanism, it resulted in duplication of the $B C R-A B L$ gene, as often seen in standard $t(9 ; 22)$ CML with an extra $\mathrm{Ph}$ chromosome. In 3 out of 20 cells from patient 2 , only one chromosome 9 was marked with the $B C R$ probe. This could be due to a lack of sensitivity of the hybridization experiment or it could indicate the presence of a cell population with one normal and one rearranged chromosome 9 , as in patient 1 , whereas the majority of the cells contained two rearranged chromosomes 9. Twocolor hybridization of $B C R$ (FITC) and $A B L$ (TRITC) probes on interphase nuclei from patient 2 showed many cells with two bicolored (TRITC/ FITC) spots and a third FITC signal confirming 

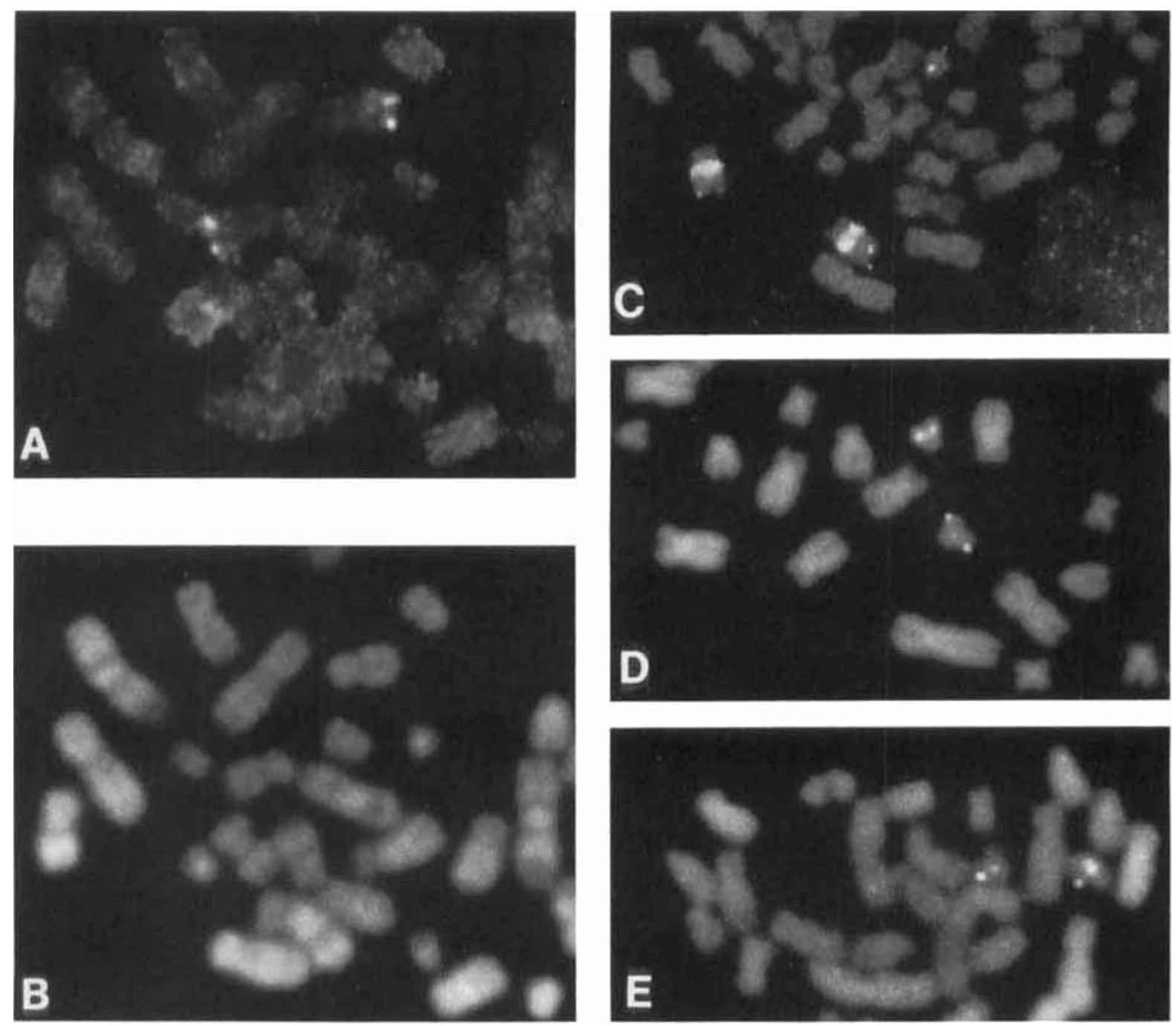

Figure 4. Partial metaphases from patient 2 showing the results of FISH. A: Cos-ABL- 18 probe on both chromosomes 9. B: DAPI staining of the same metaphase. C: Co-hybridization of pHUR98 (chromosome 9) and Cos-BCR-16 probe showing 3 BCR signals on both chromosomes 9 and one 22. D: $\operatorname{Cos} \lambda 3.1$ and $E$ : Cos 40D2, both probes on both chromosomes 22 .

the findings on metaphase chromosomes. Two months after the start of therapy, when the peripheral WBC had dropped to $12 \times 10^{9} / 1$ and the differential count showed $18 \%$ lymphocytes, a PHA stimulated blood culture was done and metaphase chromosomes were hybridized to the probes. Ten metaphase cells were analyzed for each probe, which showed a hybridization pattern corresponding to normal, non-rearranged cells, i.e., $A B L$ on both chromosomes $9, B C R, \lambda 3.1$, and 40D2 on boch chromosomes 22 (Table 2). This indicated absence of $B C R-A B L$ rearrangement in T-lymphocytes, as expected. A control hybridization was done on bone marrow cells, 6 months after the beginning of therapy. Three signals for $B C R$ were seen in 15 out of 15 metaphases and in $78 \%$ of the nuclei, indicating the persistence of a double $B C R$ $A B L$ recombination in a substantial percentage of marrow cells.

\section{RFLP Analysis}

To further investigate the mechanism by which both chromosomes 9 are involved in $\mathrm{Ph}$ rearrangement in patient 2, RFLP analysis of polymorphic markers of $9 q$ was performed on bone marrow and blood from the patient as well as on blood from his mother. At the time of study, blood from the patient contained a mixture of leukemic cells and normal lymphocytes. Material from the father was not available. The results showed a partial loss of 
BCR-ABL LOCALIZATION ON 9q34 IN PH-NEG CML

TABLE 2. Number of Mitoses Scored and Chromosome Localization of FITC Signals Obtained After Hybridization of Metaphase Chromosomes From the Two $\mathrm{Ph}(-) \mathrm{CML}$ Patients

\begin{tabular}{|c|c|c|c|c|c|c|c|c|c|c|c|c|}
\hline \multirow[b]{3}{*}{ Probes } & \multicolumn{4}{|c|}{ Patient I } & \multicolumn{4}{|c|}{ Patient 2} & \multicolumn{4}{|c|}{ Patient 2} \\
\hline & \multicolumn{4}{|c|}{ Bone marrow at diagnosis } & \multicolumn{4}{|c|}{ Bone marrow at diagnosis } & \multicolumn{4}{|c|}{ Lymphocyte culture } \\
\hline & $9^{\mathrm{a}}$ & 9 & 22 & 22 & 9 & 9 & 22 & 22 & 9 & 9 & 22 & 22 \\
\hline Cos-ABL- 18 & $22^{\mathrm{b}}$ & 22 & 0 & 0 & 25 & 25 & 0 & 0 & 10 & 10 & 0 & 0 \\
\hline Cos-BCR-16 & 35 & 0 & 35 & 0 & 20 & 17 & 20 & 0 & 0 & 0 & 10 & 10 \\
\hline $\operatorname{Cos} \lambda 3.1$ & 0 & 0 & 16 & 16 & 0 & 0 & 20 & 20 & 0 & 0 & 10 & 10 \\
\hline $40 \mathrm{D} 2$ & 0 & 0 & 36 & 36 & 0 & 0 & 20 & 20 & 0 & 0 & 10 & 10 \\
\hline
\end{tabular}

a9 means $9 q 34$ and 22 means $22 q 11$.

bumber of mitoses showing a positive FITC signal on the given chromosome.

some maternal chromosome 9 alleles (Fig. 5; Table $3)$. The proximal marker $26 \mathrm{p}$ retained heterozygosity, while the more distal markers hAK1B3.25, ASSg1, MCT136, and EFD126.3 showed homozygosity (or hemizygosity) in the bone marrow cells and the majority of blood cells (Fig. 5, lanes $A$ and $B$, respectively). In particular, the maternal alleles for ASSG1 and EFD126.3 markers were absent from the parient's bone marrow. This can be explained by assuming that in the leukemic cells a mitotic recombination had occurred between 26p and AK1, resulting in homozygosity of all paternal alleles on chromosome 9 , at band $\mathrm{q} 34$, including duplication of the $B C R-A B L$ gene. These results also suggest that the paternal chromosome 9 was involved in the formation of the $B C R-A B L$ hybrid gene in this patient.

\section{DISCUSSION}

Analyses of leukemic cells from 2 CML patients showed a normal karyotype but molecular changes corresponding to a $\mathrm{Ph}$ translocation. FISH with cosmids specific for $3^{\prime} A B L$ and $5^{\prime} B C R$ showed aberrant localization of $5^{\prime} B C R$ sequences on chromosome band $9 \mathrm{q} 34$. As evidenced by RNA-PCR, a classic $B C R-A B L$ mRNA was encoded in both cases. This is to the best of our knowledge the first time that relocation of $5^{\prime} B C R$ sequences to chromosome 9 is documented. A number of other cases of CML with an apparently normal karyotype have been investigated. In at least six cases, translocation or insertion of $A B L$ sequences on one chromosome 22 within the $B C R$ gene was demonstrated (Morris et al. 1986, 1990; Ganesan et al., 1986; Dreazan et al., 1987; Inazawa et al., 1989), whereas in at least three cases $B C R$ and $A B L$ sequences were shown to be located on different chromosome arms like 1p or 20p (Van der Plas et al., 1989; Morris et al., 1991). The latter situation

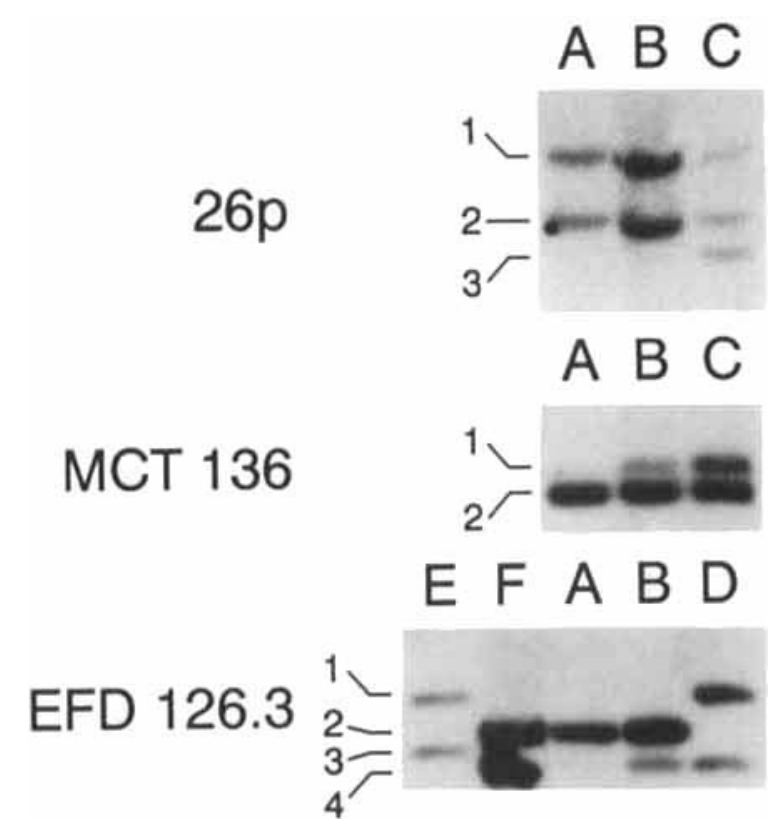

Figure 5. Restriction fragment length polymorphisms detected by the probes 26p (BstXI), MCTI 36 (HindlII), and EFDI26.3 (Toql). Lanes A: bone marrow DNA from patient 2; B: DNA from peripheral blood, obtained from patient 2 after treatment; $C$ : pooled DNA from nine controls ( 18 different chromosomes, displaying all possible alleles); D: DNA from the mother of patient 2; E,F: DNA from two controls, known to have alleles $1-3$ and 2-4 at EFD 1 26.3. The Hindlll polymorphism detected by MCTI 36 is a still unpublished RFLP with fragment sizes of 2.3 and $2.5 \mathrm{~kb}$. Analysis of 100 unrelated individuals revealed complete linkage disequilibrium between the HindIII RFLP and the already published Pstl RFLP at this locus. The autoradiographs clearly show retention of heterozygosity at 26p and homozygosity in lane A detected by MCTI 36 and EFD 126.3. The unequal ratio of both alleles in lane $B$ detected by MCT 136 and EFD 126.3 indicates that even after treatment the myeloid cells still contain the BCR-ABL duplication.

is more often observed when changes of $9 \mathrm{q} 34$ are visible cytogenetically (Bartram et al., 1985; Kurzrock et al., 1986; Van der Plas et al., 1989). In the latter cases there are often residual $3^{\prime} B C R$ sequences on the $\operatorname{der}(9)$ that suggest occurrence of at least two successive translocations, i.e., $t(9 ; 22)$ followed by translocation between the $\operatorname{der}(22)$ and 
TABLE 3. Genotypic Data of Chromosome 9 Markers From Patient 2 and His Mother ${ }^{\mathbf{a}}$

\begin{tabular}{llllcc}
\hline & & & \multicolumn{3}{c}{ Genotype } \\
\cline { 3 - 6 } Probe & $\begin{array}{c}\text { Chromosome } \\
\text { localization }\end{array}$ & Enzyme & $\begin{array}{c}\text { Patient 2 } \\
\text { (blood) }\end{array}$ & $\begin{array}{c}\text { Patient 2 } \\
\text { (bone marrow) }\end{array}$ & $\begin{array}{c}\text { Mother } \\
\text { (blood) }\end{array}$ \\
\hline 26p & $9 q 12-q 13$ & BstXI & $1-2$ & $1-2$ & n.a. \\
hAKIB3.25 & $9 q 34.1$ & Taql & $1-2$ & $1-1$ & $1-2$ \\
ASSgI & $9 q 34.1$ & HindIII & $1-2$ & $1-1$ & $2-2$ \\
MCTI36 & $9 q 34.3$ & HindIII & $1-2$ & $1-1$ & n.a. \\
EFDI26.3 & $9 q 34$ & Taql & $2-4$ & $2-2$ & $1-4$ \\
\hline
\end{tabular}

a Markers are listed in chromosomal order from centromere to telomere. Marker ASSg I maps within I cM from ABL (Povey et al., 1992). Bone marrow cells were obtained at diagnosis; peripheral blood was drawn 6 months after start of therapy and contained $12 \%$ of lymphocytes and $88 \%$ of myeloid cells. n.a.-not analyzed.

a third chromosome, displacing the $B C R-A B L$ chimeric gene and restoring an apparent integrity of chromosome 22 at the cytogenetic level.

Our observations in the two cases reported here suggest that $B C R$ sequences were inserted at the $5^{\prime}$ side of the $A B L$ gene. But investigation at the genomic level using pulsed-field gel electrophoresis (PFGE) or cloning and sequencing have not been performed and we cannot exclude the possibility of two successive translocations, first a classic $t(9 ; 22)$ followed by a second translocation between both derivatives, i.e., $9 q+$ and $22 q-$, masking the first chromosomal exchange.

FISH with specific cosmid probes is a highly efficient tool for the study of such cases: they provide clear hybridization signals on both chromatids of the target chromosomes which are clearly distinguishable from background hybridization signals. Furthermore, all mitotic cells are informative. Using two-color FISH it is possible to see the confluence of labeled sequence on the same chromosome band, while the homologous chromosome carries only one of the genes. This is particularly important in cases where rearranged chromosomes are not morphologically distinguishable from their normal homologs.

The cases studied here should make cytogeneticists aware of the fact that use of FISH with only the $A B L$ probe to analyze $\mathrm{Ph}$-negative CML can be misleading: FISH of $A B L$ probe in our two cases conformed with a normal karyotype. Hybridization of $5^{\prime} B C R$ sequences indicated abnormality, as did the molecular studies.

Duplication of the $\mathrm{Ph}$ is a frequent evolutionary event in CML. In patient 2, we showed that duplication occurred by somatic crossing over of the long arm of chromosome 9 and loss of maternal alleles. Reeve et al. (1988) described a similar phe- nomenon, i.e., loss of germline $B C R$ sequences and duplication of rearranged $B C R$ sequences as well as acquired homozygosity of $I G L$ sequences. Other genes on chromosome 22 were not investigated. In our patient 2, duplication of the $B C R$ $A B L$ allele allowed the use of RFLP analysis. Our study indicated that the rearranged chromosome 9 was of paternal origin, which is in line with the results reported recently by $\mathrm{Haas}$ et al. (1992). These authors analyzed the cytogenetically polymorphic regions on $9 \mathrm{q} 11$ and $22 \mathrm{p} 11$ in $15 \mathrm{CML}$ patients with $\mathrm{t}(9 ; 22)$ and their parents. The $9 \mathrm{q}+$ was shown to be of paternal origin and the $22 q-$ of maternal origin. In our patient 2 , the proximal part of the duplicated chromosome 9 (marker 26p, Fig. 5 ) retained heterozygosity and hence was of maternal origin.

The difference in band intensity for MCT136 and EFD126.3 in the peripheral blood sample (Fig. 5, lane B) reflects the abnormal ratio between myeloid cells carrying the duplication and the number of lymphocytes, which have been shown by FISH (Table 2) not to carry the $B C R-A B L$ hybrid gene and thus to contain both maternal and paternal alleles.

\section{ACKNOWLEDGMENTS}

This work was supported in part by the Netherlands Cancer Foundation and the Netherlands Prevention Fund (grant 28-1723). The authors thank Peter Heuting and Guido Breedveld for making the MCT136-HindIII material available, M. van Til for cytogenetic analysis of patient 2, R. Boucke for typing the manuscript, and Mirko Kuit and Tom de Vries Lentsch for photographic support.

\section{REFERENCES}

Arnoldus EPJ, Wiegant J, Noordermeer IA, Wessels JW, Bevestock GC, Grosveld GC, van der Ploeg M, Raap AK (1990) Detection 
of the Philadelphia chromosome in interphase nuclei. Cytogenet Cell Genet 54:108-111.

Bartram CR, Kleihauer E, de Klein A, Grosveld G, Teyssier JR, Heiscerkamp N, Groffen $J(1985) c-a b /$ and $b c r$ are rearranged in a $\mathrm{Ph}^{1}{ }^{1}$-negative CML patient. EMBO J 4:683-686.

Chomczynski P, Sacchi N (1987) Single-step method of RNA isolation by acid guanidinium thiocyanate-phenol-chloroform extraction. Anal Biochem 162:156-159.

Dreazen O, Rassool F, Sparkes RS, Klisak I, Goldman JM, Gale RP (1987) Do oncogenes determine clinical features in chronic myeloid leukacmia? Lancet I: 1402-1405.

Dubé I, Dixon J, Beckett T, Grossman A, Weinstein M, Benn P, Mckeithan T, Norman C, Pinkerton P (1989) Location of breakpoints within the major breakpoint cluster region (BCR) in 33 patients with bcr-rearrangement-positive chronic myeloid leukemia (CML) with complex or absent Philadelphia chromosomes. Genes Chrom Cancer 1:106-111.

Ganesan TS, Rassool F, Guo A-P, Th'ng KH, Dowding C, Hibbin JA, Young BD, White H, Kumaran TO, Galton DAG, Goldman JM (1986) Rearrangement of the bre gene in Philadelphia chromosome negative chronic myeloid leukemia. Blood 68:957-960.

Haas OA, Argyriou-Tirita A, Lion T (1992) Parental origin of chromosomes involved in the $t(9 ; 22)$. Nature 359:414-416.

Hagemeijer A, Smit EME, Bootsma D (1979) Improved identification of chromosomes of leukemic cells in methotrexate treated cultures. Cytogenet Cell Genet 23:208-212.

Hagemeijer A, Bartram CR, Smit EME, van Agthoven AJ, Bootsma D (1984) Is the chromosomal region 9q34 always involved in the variants of the Ph translocation? Cancer Genet Cytogenet 13:116.

Hagemeijer A, de Klein A, Godde-Salz E, Turc-Carel C, Smit EME, van Agthoven AJ, Grosveld GC (1985) Translocation of c-abl to "masked" $\mathrm{Ph}$ in chronic myeloid leukemia. Cancer Genet Cytogenet 18:95-104.

Heisterkamp N, Stam K, Groffen J, de Klein A, Grosveld G (1985) Structural organization of the bcr gene and its role in the $\mathrm{Ph}$ translocation. Nature 315:758-761.

Hermans A, Gow L, Selleri M, von Lindern M, Hagemeijer A, Wiedeman LM, Grosveld G (1988) Bcr-abl oncogene activation in Philadelphia chromosome positive acute lymphoblastic leukemia. Leukemin 2:628-633.

Inazawa J, Nishigaki $H$, Takahira $H$, Nishimura J, Horiike S, Taniwaki M, Misawa S, Abe T (1989) Rejoining between $9 q+$ and Philadelphia chromosomes results in normal looking chromosomes 9 and 22 in $\mathrm{Ph}^{1}$-negative chronic myelocytic leukemia. Hum Genet 83:115-118.
ISCN (1991) Guidelines for Cancer Cyrogenetics. Supplement to an International System for Human Cytogenetic Nomenclature. Mitelman F (ed). Basel: S. Karger.

Kurzrock R, Blick MB, Talpaz M, Velasquez WS, Trujillo JM, Kouttab NM, Kloetzer WS, Arlinghaus RB, Gutterman JU (1986) Rearrangement in the breakpoint cluster region and the clinical course in Philadelphia-negative chronic myelogenous leukemia. Ann Intern Med 105:673-679.

Martiat P, Michaux JL, Rodhain J, for the Groupe Français de Cytogénétique Hematologique (1991) Philadelphia-negative $(\mathrm{Ph}-)$ chronic myeloid leukemia (CML): Comparison with $\mathrm{Ph}(+) \mathrm{CML}$ and chronic myelomonocytic leukemia. Blood 78: 205-211.

Morris CM, Reeve AE, Fitzgerald PH, Hollings PE, Beard MEJ, Heaton DC (1986) Genomic diversity correlates with clinical variation in $\mathrm{Ph}^{1}$-negative chronic myeloid leukemia. Nature 320:281283.

Morris CM, Rosman I, Archer SA, Cochrane JM, Fitzgerald PH (1988) A cytogenetic and molecular analysis of five variant Philadelphia translocations in chronic myeloid leukemia. Cancer Genet Cytogenet 35:179-197.

Morris CM, Heisterkamp N, Kennedy MA, Fitzgerald PH, Groffen J (1990) Ph-negative chronic myeloid leukemia: Molecular analysis of ABL insertion into M-BCR on chromosome 22. Blood $76: 1812-1818$.

Morris C, Kennedy M, Heisterkamp N, Columbano-Green L, Remeril K, Groffen J, Fitzgerald P (1991) A complex chromosome rearrangement forms the BCR-ABL fusion gene in leukemic cells with a normal karyotype. Genes Chrom Cancer 3:263-271.

Povey S, Smith M, Haines J, Kwiatkowski D, Fountain J, Bole A, Abbott C, Jackson I, Lawrie M, Hulten M (1992) Report on the First International Workshop on Chromosome 9. Ann Hum Genet 56:167-221

Reeve AE, Morris CM, Fitzgerald PH (1988) Acquired homozygosity of the rearranged $b c r$ allele during the acute leukemic phase of a patient with $\mathrm{Ph}$-negative chronic myeloid leukemia. Blood 72: 24-28.

Van der Plas DC, Hermans ABC, Soekarman D, Smit EME, de Klein A, Smadja N, Alimena G, Goudsmit R, Grosveld G, Hagemeijer A (1989) Cytogenetic and molecular analysis in Philadelphia negative CML. Blood 73:1038-1044.

Van der Plas DC, Grosveld G, Hagemeijer A (1991) Review of clinical, cytogenetic and molecular aspects of Ph-negative CML. Cancer Genet Cytogenet 52:143-156. 